\title{
Radial distribution of sap flux density in trunks of a mature beech stand
}

\author{
Dietmar LÜTTSCHWAGER*, Rainer REMUS \\ Leibniz Centre for Agricultural Landscape Research, 15374 Müncheberg, Germany
}

(Received 11 July 2006; accepted 13 December 2006)

\begin{abstract}
In a mature beech stand located in north-eastern Germany, xylem sap flux measurements were continuously performed during the 2002-2004 growing seasons. Ten representative trunks were studied using heated thermal dissipation probes. The measurements aimed at identifying principles governing radial profiles of xylem flux in beech trunks. The measurements were taken up to a trunk depth of $132 \mathrm{~mm}$. The sap flow density in the pericambial xylem was found to vary among trees of different diameters, but was not considerably smaller in suppressed trees. A model for the radial distribution of sap flux density was formulated relating trunk radius and sap flow density. The model takes into account different trunk diameter. About $90 \%$ of the sap flux was found to occur in the outer two fifths of the trunk. Using this model, an adequate estimate of transpiration can be achieved at tree and stand level, even when the sap flux measurements are restricted to the outer trunk sectors.
\end{abstract}

sap flow density / radial model / beech

Résumé - Distribution radiale du flux de sève dans les troncs d'un peuplement de hêtres. Nous avons mesuré les densités de flux de xylème dans le tronc de 10 individus représentatifs d'un peuplement de hêtres du nord-est de l'Allemagne. Ces mesures ont été conduites pendant les périodes de végétation de 2002 à 2004 en utilisant des sondes à dissipation de chaleur. Le but était de décrire les gradients radiaux de flux de sève dans le tronc des hêtres. Les mesures ont été réalisées jusqu'à une profondeur de $132 \mathrm{~mm}$. La densité de flux de sève du xylème de la zone cambiale variait d'arbre en arbre en fonction du diamètre, mais cette densité ne diminuait pas sensiblement dans les arbres dominés. Un modèle de distribution radiale de la densité de flux de sève a été mis au point dans lequel le diamètre du tronc et la densité du flux de sève sont mis en relation. Le modèle prend en considération les arbres ayant des troncs de diamètres différents. Environ $90 \%$ de l'eau circule dans les deux cinquièmes extérieurs du tronc. De cette façon, il est possible de calculer de manière suffisamment exacte la transpiration de l'arbre ou du peuplement tout entier, même si les mesures du flux de sève se limitent à la zone externe du tronc.

densité de flux de sève / modèle radial / hêtre

\section{INTRODUCTION}

Transpiration constitutes a major component of matter flow in a forest ecosystem. Plant transpiration is powered by the water potential gradient in the soil-plant-atmosphere continuum (SPAC) [15]. Compared to evaporation, transpiration has proved far more difficult to estimate by means of modelling, because it is tightly controlled by stomata and plant-internal resistances. The hydraulic architecture of a tree is known to constrain the water flux from roots to leaves. Plant water budget and gas exchange are limited by the hydraulic conductivity of the xylem. Therefore, measurement-based surveys of transpiration have proved to be a prerequisite for the estimation of the water balance in forest ecosystems. In addition, they allow to distinguish the transpiration of different vegetation layers. Xylem sap flux measurements on trees and tree stands are an appropriate technique for that purpose because, at a daily or longer pace, total canopy transpiration equals approximately the water flow through the trunks [16]. The mass flow of water in trunks is mainly computed as the product of sap flow den-

* Corresponding author: dluettschwager@zalf.de sity (SFD; water mass per conducting area and time) and cross sectional area of water conducting sapwood.

However, large errors may occur when sap flow is scaled from single point measurement to whole tree without the knowledge of radial sap flow profiles in the trunk. Radial sapflow profiles may vary to a large extent depending on wood anatomy. Trees with ring-porous sapwood, e.g. oak, often conduct water in only the outermost annual growth rings [13]. In contrast, conifers with tracheids conduct water through a larger cross section (sapwood), whilst heartwood is completely isolated from the water conducting network [3, 6, 22]. Radial profiles can change with time. Ford et al. found in pine trees that radial profiles of sap flow density were steeper earlier in the day and less steep later. They hypothesized that water moving in the inner sapwood requires a larger water potential gradient because of a smaller hydraulic conductivity [9].

Beech trees display a diffuse porous xylem anatomy with smaller vessels than oaks. They are known to sometimes develop coloured, false heart-wood without any noticeable decrease of water content [7]. Therefore, in beech trunks it is almost impossible to estimate the water conducting cross 
sectional area with visual methods, or by measuring the water content in the wood. But beech trees also display a radial variation of sap flow density, which makes it difficult to scale up from local sap flow density to whole trunk sap flow [26]. The relatively few data available in the literature on radial sap flow profiles in beech trunks display a large diversity $[14,17-19,21]$. This is probably due to the fact that they did not sufficiently consider tree age and social position in the canopy, which may severely influence radial profiles. For trees of the same age in a forest stand, even-aged tree rings are expected to present similar values of hydraulic conductivity. This is at least the case, if potential changes result from weather anomalies during the development of the tree ring. It is therefore assumed that in trees with different diameters, normalised radial profiles of sap flow density display a smaller variability among trees as compared to radial profiles based on absolute depths.

The aim of this study was to detect general principles that describe the radial variability of xylem sap flux in beech trunks. The use of a model for radial SFD distribution that takes into account trees of different trunk diameter in the stand, should therefore enable researchers to run sap flux measurements only in the outer sapwood section and to nevertheless derive stand level transpiration from these data.

\section{MATERIALS AND METHODS}

\subsection{Stand description}

We studied a 117-year old beech (Fagus silvatica L.) stand located in the forest district of Beerenbusch near Rheinsberg in northern Brandenburg, about $600 \mathrm{~m}$ west of lake Stechlinsee $\left(53.1^{\circ} \mathrm{N}\right.$, 13.0 $0^{\circ}$ E, a.s.1.: $78 \mathrm{~m}$ ). The stand was established during 1888 as a plantation under Scots pine (Pinus sylvestris L.) trees. Following the clearing of pine trees between 1985 and 1988, a pure beech stand evolved. Since then, the beech trees have reached a mean height of $27.3 \mathrm{~m}$, with trunk diameter and basal area averaging $33.4 \mathrm{~cm}$ and $24.9 \mathrm{~m}^{2} \mathrm{ha}^{-1}$, respectively. The leaf area index ranged between 6.0 and 6.4. The 7.4 ha stand had a $93 \%$ canopy cover, and was growing on a groundwater-distant, weakly degraded soil (Dystric Arenosol; FAO classification 1974, humus: moder). An experimental plot covering 0.5 ha and comprising 108 beech trees was established.

\subsection{Weather conditions and soil water content}

Mean annual temperature (1951-2000) and precipitation were $8.0{ }^{\circ} \mathrm{C}$ and $586 \mathrm{~mm}$ (Neuglobsow Station of the German Meteorological Service, distance $3 \mathrm{~km}$ ). Our weather station was located in an open field approximately $2 \mathrm{~km}$ away from the experimental stand. Air temperature and relative humidity $\left({ }^{\circ} \mathrm{C}\right.$ and $\%$, Lambrechtsensors type 8092 , recording every $10 \mathrm{~min})$, global radiation $\left(\mathrm{J} \mathrm{cm}^{-2}\right.$, type 16103 , recorded every $1 \mathrm{~s}$ ), and precipitation (mm, type 15188 Joss-Tognini) were recorded and data logged as 10 min means (ADLAS II, Lambrecht). Soil water content (vol \%) was measured hourly at $0.5 \mathrm{~m}, 1.5 \mathrm{~m}$ and $2.5 \mathrm{~m}$ from a dominant tree to $0.2 \mathrm{~m}$ soil depth (Theta-probe ML2x, Delta-T).
Table I. Diameter at $1.3 \mathrm{~m}$ and tree height of the measured beech trees and sapwood depths (positions of the thermocouples), in which sap flow was measured Trees 91, 93, 73, 92, 82, 51, 29 were used for modelling the radial SFD profile.

\begin{tabular}{|c|c|c|c|c|c|c|c|c|c|}
\hline \multirow[t]{2}{*}{$\begin{array}{l}\text { Basal area } \\
\text { class }\end{array}$} & \multirow[t]{2}{*}{ Tree number } & \multirow[t]{2}{*}{$\mathrm{d}_{1.3}(\mathrm{~cm})$} & \multirow[t]{2}{*}{ Height (m) } & \multicolumn{6}{|c|}{$\begin{array}{l}\text { Sap flow measurement } \\
\text { in sapwood depth }(\mathrm{mm})\end{array}$} \\
\hline & & & & 11 & 33 & 55 & 77 & 99 & 121 \\
\hline & $2002-2003$ & & & & & & & & \\
\hline 1 & 48 & 58.4 & 32.6 & $x$ & $\times$ & $x$ & & & \\
\hline 2 & 55 & 55.2 & 31.4 & $x$ & $x$ & & & & \\
\hline 3 & 63 & 52.1 & 32.0 & $x$ & & & & & \\
\hline 4 & 56 & 48.6 & 32.1 & $x$ & & & & & \\
\hline 5 & 65 & 45.1 & 31.6 & $x$ & $x$ & & & & \\
\hline 6 & 75 & 43.9 & 29.4 & $x$ & & & & & \\
\hline 7 & 57 & 39.3 & 31.0 & $x$ & & & & & \\
\hline 8 & 52 & 35.5 & 29.1 & $x$ & $\times$ & & & & \\
\hline 9 & 50 & 32.5 & 27.6 & $\times$ & & & & & \\
\hline 10 & 54 & 24.1 & 24.3 & $\times$ & $x$ & & & & \\
\hline & 2004 & & & & & & & & \\
\hline 1 & 91 & 60.2 & 31.4 & $x$ & $\times$ & $x$ & & & \\
\hline 2 & 93 & 56.3 & 31.6 & $x$ & $x$ & & & & \\
\hline 3 & 99 & 52.5 & 32.4 & $x$ & & & & & \\
\hline 4 & 73 & 49.3 & 30.6 & $\times$ & $x$ & & & & \\
\hline 5 & 80 & 46.5 & 31.8 & $x$ & & & & & \\
\hline 6 & 92 & 43.9 & 29.6 & $x$ & $x$ & & & & \\
\hline 7 & 101 & 41.0 & 30.3 & $\times$ & & & & & \\
\hline 8 & 82 & 37.0 & 30.4 & $x$ & $x$ & & & & \\
\hline 9 & 68 & 34.7 & 32.2 & $x$ & & & & & \\
\hline 10 & 100 & 18.8 & 22.1 & $\times$ & & & & & \\
\hline 1 & 51 & 67.8 & 32.6 & $x$ & $\times$ & $x$ & $x$ & $x$ & $\times$ \\
\hline 6 & 29 & 43.9 & 31.6 & $\times$ & $\times$ & $\times$ & $\times$ & & \\
\hline
\end{tabular}

Potential evapotranspiration (PET, mm day ${ }^{-1}$ ) was calculated using the Penman-Monteith equation [23]:

$$
\mathrm{PET}=\frac{\Delta\left(R_{\mathrm{n}}-G\right)+\rho_{\mathrm{a}} c_{\mathrm{p}} \frac{\left(e_{\mathrm{s}}-e_{\mathrm{a}}\right)}{r_{\mathrm{a}}}}{\Delta+\gamma\left(1+\frac{r_{\mathrm{s}}}{r_{\mathrm{a}}}\right)}
$$

where $R_{\mathrm{n}}$ is the net radiation ( $\mathrm{MJ} \mathrm{m}{ }^{-2}$ day $^{-1}$ ), $G$ the soil heat flux (MJ $\left.\mathrm{m}^{-2} \mathrm{day}^{-1}\right),\left(e_{\mathrm{s}}-e_{\mathrm{a}}\right)$ represents the vapour pressure deficit of the air $[\mathrm{kPa}], \rho_{\mathrm{a}}$ is the mean air density at constant pressure, $c_{\mathrm{p}}$ is the specific heat of the air, $\Delta$ represents the slope of the saturation vapour pressure temperature relationship $\left(\mathrm{kPa}^{\circ} \mathrm{C}^{-1}\right), \gamma$ is the psychrometric constant $\left(\mathrm{kPa}^{\circ} \mathrm{C}^{-1}\right)$. In default of wind speed measurements the aerodynamic resistance $r_{\mathrm{a}}\left(\mathrm{s} \mathrm{m}^{-1}\right)$ and the surface resistance $r_{\mathrm{s}}\left(\mathrm{s} \mathrm{m}^{-1}\right)$ were set to constant values of 3.5 and 90 , respectively (Hörmann, pers. comm.).

\subsection{Selection of trees for sap flux measurements}

Trees (108 individuals) were grouped in 10 classes with similar cumulated basal area $\left(A_{\text {bas }}\right)$, but different numbers of trees. We selected one representative tree with median basal area in each class for xylem sap flux measurements (Tab. I). These measurements were 
made at a depth of $0-22 \mathrm{~mm}$ for all trees; at $22-44 \mathrm{~mm}$ on 5 trees and at $44-66 \mathrm{~mm}$ for a single, very large tree. Different trees were measured during 2004 with a similar sampling procedure. Furthermore, to estimate SFD in deep wood sectors more, sap flux measurements were performed over 11 weeks at six depths up to $132 \mathrm{~mm} \mathrm{(39 \%}$ trunk radius, tree 51) at four depths up to $88 \mathrm{~mm}$ (40\% trunk radius, tree 29).

\subsection{Sap flux density measurements}

Sap flux density was measured with constant power thermal dissipation probes according to Granier [12]. All xylem sap flux sensors and the electronic control and energy supply units were selfmade. Sensors were heated by rechargeable $12 \mathrm{~V}$ DC batteries. The measured values $(\mathrm{mV}$ between thermocouples connected in series in the heated and unheated sensors) were recorded at $10 \mathrm{~s}$ intervals and stored as 30 min mean values (21X, Campbell Scientific). Sap flux density was calculated from thermal dissipation [12]. To avoid any thermal impacts from radiation, sensors were installed on the northeast-facing side of the trunk although earlier measurements did not evidence any systematic deviation on account of cardinal direction. Whole tree sap flux was computed as the product of SFD and the area of the sapwood.

\subsection{Radial profiles}

To model the radial SFD profile we used daily sums of SFDs from seven beech trees with 2-6 probes in the trunk (Tab. I). Days with PET $<1 \mathrm{~mm}$ were skipped. Hence, four means of daily SFD-totals were computed over 16-days intervals (Tab. V).

All trees were of the same age and displayed the same number of annual increment rings. We normalised SFD profiles as a function of trunk radius: maximal values of sap flow density were set to $1\left(\mathrm{SFD}_{\text {rel }}=100 \%\right)$, while the radius was similarly set to 1 .

The model was developed based on following considerations: (1) Maximal values of SFD are found typically in the outer xylem; (2) SFD decreases towards the center of the trunk due to increased frequency of embolised and inactive xylem elements; (3) the hydraulic conductivity of the youngest xylem elements close to the cambium increases with maturation; and (4) there is no xylem sap flux in the cambium (at radial distance zero). Two combined models were developed, one for the sector close to the cambium, using a modified growth function (Eq. (2)) and a second one describing hydraulic conductivity in the xylem, using a decay function (Eq. (3)).

Equation (4) is the product of both equations. The standardised radius $r$ was involved as a factor for fitting with an additive correction link to trim the function towards zero (schematical illustration in Fig. 1).

$$
\begin{aligned}
y_{1} & =\alpha\left(1-\mathrm{e}^{-\beta r}\right) \\
y_{2} & =\alpha \mathrm{e}^{-\gamma r} \\
\mathrm{SFD}_{\text {rel }} & =\alpha\left(1-\mathrm{e}^{-\beta r}\right)\left(\alpha \mathrm{e}^{-\gamma r} r+(\delta-\varepsilon r)\right)
\end{aligned}
$$

The model was fitted to the collected data $(n=80)$ by an iterative procedure. Model performance was assessed from the coefficient of determination $\left(R^{2}\right)$ for non-linear regression analysis as recommended by Kvålseth [20].

To calculate whole tree transpiration, we substituted $\mathrm{SFD}_{\text {rel }}=$ $100 \%$ and the standardised radius in the model with the maximal

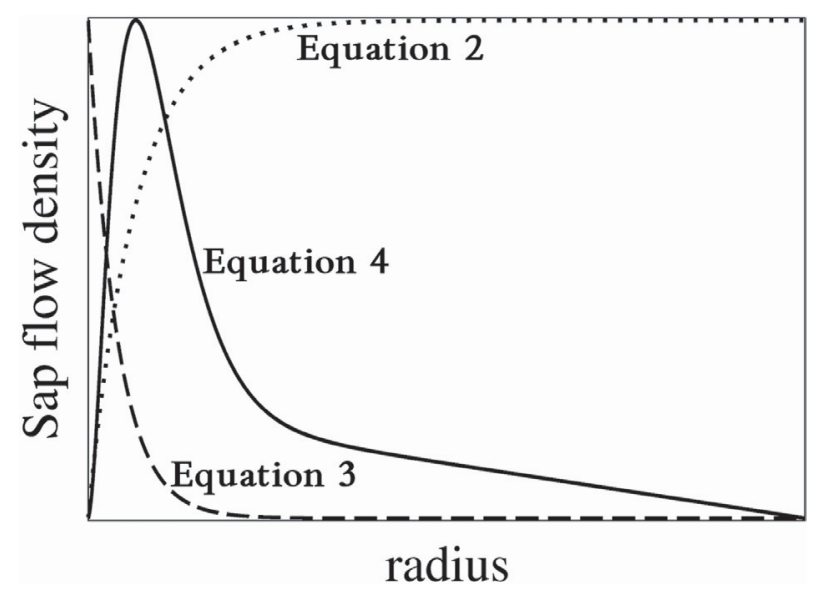

Figure 1. Schematic illustration of the two combined models for radial distribution of sap flux density: the sector close to the cambium was described by a growth function (Eq. (2)) and the interior sector by a decay function (Eq. (3)). Equation 4 is the product of both equations.

measured SFD-value and the real radius of the trunk, respectively. Related SFD-values from the model were multiplied with the annuli of the cross sectional area of the trunk in one tenth of percent radial steps. Whole tree transpiration ( $\mathrm{kg}$ per tree) was the sum of these products.

\section{RESULTS}

\subsection{Weather conditions and soil water content}

Table II presents 10-day mean values of soil water content, and seasonal values of precipitation and evapotranspiration for 2002-2004. The year 2002 proved to be very moist (aboveaverage precipitation of $813 \mathrm{~mm}$ ), while 2003 was marked by a precipitation deficit of about $100 \mathrm{~mm}$ with minimum soil moisture values occurring during summer. In contrast, during 2004 soil water content remained high. The mean values of relative humidity of the air decreased more than $10 \%$ in the summer months of 2003 compared to the summer in other years.

\subsection{Seasonal and stand variability of sap flux density}

Daily sap flux density recorded between 0-22 $\mathrm{mm}$ behind the cambium averaged 11.07 (3.46), 9.61 (2.06) and 10.97 (3.52) kg dm ${ }^{-2} \mathrm{~d}^{-1}$ during 2002, 2003 and 2004, respectively. A comparison of beech trees with different trunk diameters revealed a large variability of SFD (0-22 mm) among individual trees, with no obvious relationship to tree diameter (Tab. III).

Mean cumulated daily SFD at a wood depth of 22-44 mm $(n=5)$ amounted to 7.79 (2.08), 7.77 (2.04) and 7.64 (4.19) $\mathrm{kg} \mathrm{dm}^{-2} \mathrm{~d}^{-1}$ during 2002, 2003 and 2004, respectively; they were about $30 \%$ smaller than values at $-22 \mathrm{~mm}$ depth during 2002 and 2004, and about 20\% smaller during 
Table II. Total precipitation, potential Penman-Monteith evapotranspiration (PET) and mean volumetric soil water content (three sensors of different distance to a tree, standard deviation in brackets) during decades of the seasons 2002, 2003 and 2004.

\begin{tabular}{|c|c|c|c|c|c|c|c|c|c|}
\hline \multirow[b]{2}{*}{ Period } & \multicolumn{3}{|c|}{ PET (mm) } & \multicolumn{3}{|c|}{ Precipitation (mm) } & \multicolumn{3}{|c|}{ Soil water (vol\%) } \\
\hline & 2002 & 2003 & 2004 & 2002 & 2003 & 2004 & 2002 & 2003 & 2004 \\
\hline April 1-10 & 16.5 & 9.2 & 8.9 & 0.0 & 8.5 & 14.3 & $17.3(4.0)$ & $17.3(4.6)$ & $16.8(4.7)$ \\
\hline April 11-20 & 3.8 & 19.8 & 13.9 & 40.2 & 2.2 & 11.5 & $18.4(3.9)$ & $17.2(4.8)$ & $16.8(4.8)$ \\
\hline April 21-30 & 9.5 & 22.5 & 17.1 & 17.2 & 9.6 & 3.1 & $18.6(3.7)$ & $17.0(5.0)$ & $16.4(4.8)$ \\
\hline May 1-10 & 13.8 & 24.9 & 13.4 & 22.6 & 2.8 & 17.8 & $18.7(3.5)$ & $16.1(5.0)$ & $14.9(5.5)$ \\
\hline May $11-20$ & 19.2 & 17.4 & 13.7 & 9.1 & 20.8 & 3.8 & $15.8(4.1)$ & $14.4(5.4)$ & $13.8(5.2)$ \\
\hline May 21-31 & 23.1 & 33.5 & 23.3 & 19.5 & 2.0 & 13.0 & $12.4(4.9)$ & $11.6(5.8)$ & $11.9(5.6)$ \\
\hline June $1-10$ & 23.7 & 38.1 & 25.3 & 43.0 & 12.6 & 12.4 & $11.4(5.1)$ & $10.6(5.9)$ & $11.0(5.7)$ \\
\hline June $11-20$ & 26.8 & 34.5 & 17.6 & 27.0 & 31.1 & 26.4 & $13.6(5.2)$ & $10.6(6.0)$ & $10.6(5.9)$ \\
\hline June $21-30$ & 25.4 & 34.5 & 20.3 & 16.4 & 4.5 & 10.4 & $11.6(5.3)$ & $11.1(5.8)$ & $10.2(5.9)$ \\
\hline July $1-10$ & 28.3 & 22.4 & 19.4 & 19.1 & 18.8 & 36.0 & $10.5(5.4)$ & $10.0(5.9)$ & $11.0(6.1)$ \\
\hline July 11-20 & 21.1 & 41.8 & 19.5 & 52.2 & 10.0 & 54.4 & $12.7(6.2)$ & $9.9(5.9)$ & $11.9(6.2)$ \\
\hline July $21-31$ & 29.2 & 39.6 & 25.3 & 16.3 & 37.0 & 24.2 & $13.4(6.0)$ & $12.7(5.9)$ & $12.4(6.2)$ \\
\hline Aug. 1-10 & 16.8 & 46.6 & 42.2 & 86.7 & 3.3 & 0.0 & $15.5(6.3)$ & $9.8(6.1)$ & $10.4(6.2)$ \\
\hline Aug. 11-20 & 24.9 & 43.9 & 31.7 & 28.2 & 12.6 & 43.6 & $16.4(5.1)$ & $9.6(6.0)$ & $10.7(6.1)$ \\
\hline Aug. 21-31 & 39.1 & 34.6 & 16.0 & 21.0 & 16.5 & 44.0 & $10.6(5.9)$ & $10.0(5.9)$ & $12.9(6.0)$ \\
\hline Sept. 1-10 & 31.1 & 22.3 & 23.8 & 0.0 & 24.3 & 0.0 & $10.0(6.0)$ & $10.1(5.8)$ & $11.7(6.4)$ \\
\hline Sept. $11-20$ & 18.9 & 16.0 & 23.0 & 2.9 & 25.1 & 5.0 & $10.3(6.3)$ & $12.5(5.5)$ & $10.0(6.2)$ \\
\hline Sept. 21-30 & 9.0 & 19.1 & 3.8 & 26.8 & 10.3 & 39.3 & $13.6(6.5)$ & $9.9(5.6)$ & $11.5(6.6)$ \\
\hline Oct. $1-10$ & 7.2 & 5.4 & 7.0 & 25.1 & 33.1 & 0.9 & $12.9(6.2)$ & $10.3(5.4)$ & $11.1(6.4)$ \\
\hline Oct. 11-20 & 6.1 & 5.2 & 5.7 & 20.1 & 2.9 & 13.4 & $14.3(5.9)$ & $10.1(5.3)$ & $10.3(6.0)$ \\
\hline Oct. $21-31$ & 3.8 & 3.4 & 4.0 & 42.2 & 20.4 & 10.4 & $17.7(4.3)$ & $9.9(5.3)$ & $10.3(5.9)$ \\
\hline
\end{tabular}

Table III. Cross sectional area at breast height and means of daily sap flux density of 10 beech trees. Sensor depths were 0-22 mm and 22-44 $\mathrm{mm}$ ( $n=$ days of the season, standard deviation of seasonal variability in brackets).

\begin{tabular}{|c|c|c|c|c|c|c|c|c|c|c|c|}
\hline Basal area class & & 1 & 2 & 3 & 4 & 5 & 6 & 7 & 8 & 9 & 10 \\
\hline \multicolumn{12}{|c|}{ Cross sectional area at breast height $\left(\mathrm{dm}^{2}\right)$} \\
\hline 2002-2003 & & 27.83 & 25.21 & 23.00 & 19.62 & 16.96 & 16.05 & 12.75 & 10.92 & 9.07 & 5.40 \\
\hline 2004 & & 28.43 & 24.93 & 21.66 & 19.12 & 16.96 & 15.15 & 13.19 & 10.72 & 9.44 & 2.77 \\
\hline \multicolumn{12}{|c|}{ Mean cumulated daily sap flow density at sensor depth $0-22 \mathrm{~mm}\left(\mathrm{~kg} \mathrm{dm}^{-2} \mathrm{~d}^{-1}\right)$} \\
\hline \multirow[t]{2}{*}{2002} & & 13.51 & 18.46 & 13.00 & 11.31 & 7.45 & 10.73 & 6.79 & 11.48 & 7.75 & 10.21 \\
\hline & $(n=174)$ & $(8.30)$ & $(9.93)$ & $(6.80)$ & $(6.61)$ & $(5.58)$ & $(6.48)$ & $(3.98)$ & $(7.12)$ & $(5.00)$ & $(7.43)$ \\
\hline \multirow[t]{2}{*}{2003} & & 10.11 & 12.40 & 9.86 & 11.14 & 5.93 & 8.04 & 7.84 & 11.04 & 8.08 & 11.62 \\
\hline & $(n=196)$ & (6.30) & (6.87) & (5.59) & (7.13) & $(3.53)$ & $(5.54)$ & $(5.36)$ & (6.77) & $(6.48)$ & (8.52) \\
\hline \multirow[t]{2}{*}{2004} & & 10.99 & 18.48 & 12.70 & 9.71 & 5.49 & 14.15 & 10.65 & 8.95 & 9.66 & 8.93 \\
\hline & $(n=204)$ & $(5.72)$ & (11.16) & (7.13) & $(5.72)$ & (3.98) & $(7.22)$ & $(6.54)$ & (5.29) & $(5.61)$ & (4.99) \\
\hline \multicolumn{12}{|c|}{ Mean cumulated daily sap flow density at sensor depth $22-44 \mathrm{~mm}\left(\mathrm{~kg} \mathrm{dm}^{-2} \mathrm{~d}^{-1}\right)$} \\
\hline \multirow[t]{2}{*}{2002} & & 10.90 & 7.29 & - & - & 6.04 & - & - & 5.94 & - & 8.76 \\
\hline & $(n=174)$ & $(7.32)$ & $(3.63)$ & & & $(3.89)$ & & & $(3.74)$ & & $(5.88)$ \\
\hline \multirow[t]{2}{*}{2003} & & 10.74 & 6.68 & - & - & 5.80 & - & - & 6.64 & - & 9.01 \\
\hline & $(n=196)$ & (7.03) & (3.97) & & & (3.78) & & & $(5.20)$ & & $(5.92)$ \\
\hline \multirow[t]{2}{*}{2004} & & 14.15 & 7.46 & - & 8.63 & - & 3.82 & - & 4.12 & - & - \\
\hline & $(n=204)$ & $(8.18)$ & (4.67) & & $(5.30)$ & & (2.14) & & $(2.55)$ & & \\
\hline
\end{tabular}


Table IV. Seasonal distribution (monthly mean values) of daily sap flux density in the 10 beech trees. Sensor depths were $0-22 \mathrm{~mm}(n=10)$ and $22-44 \mathrm{~mm}(n=5)$. Standard deviation in brackets. I/A is the percent $22-44 \mathrm{~mm} / 0-22 \mathrm{~mm}$.

\begin{tabular}{|c|c|c|c|c|c|c|c|c|c|}
\hline \multirow{2}{*}{$\begin{array}{l}\text { SFD } \\
\left(\mathrm{kg} \mathrm{dm}^{-2} \mathrm{~d}^{-1}\right)\end{array}$} & \multicolumn{3}{|c|}{2002} & \multicolumn{3}{|c|}{2003} & \multicolumn{3}{|c|}{2004} \\
\hline & $0-22 \mathrm{~mm}$ & $22-44 \mathrm{~mm}$ & $\mathrm{I} / \mathrm{A}$ & $0-22 \mathrm{~mm}$ & $22-44 \mathrm{~mm}$ & $\mathrm{I} / \mathrm{A}$ & $0-22 \mathrm{~mm}$ & $22-44 \mathrm{~mm}$ & $\mathrm{I} / \mathrm{A}$ \\
\hline May & $9.05(2.66)$ & $6.79(2.59)$ & $75 \%$ & $11.75(3.90)$ & $9.39(3.69)$ & $80 \%$ & $11.56(4.09)$ & $6.59(3.60)$ & $57 \%$ \\
\hline June & $14.62(4.67)$ & $10.73(4.02)$ & $73 \%$ & $16.24(3.23)$ & $12.91(3.62)$ & $80 \%$ & $14.65(6.19)$ & $9.63(4.54)$ & $66 \%$ \\
\hline July & $14.92(4.86)$ & $10.64(3.02)$ & $70 \%$ & $12.19(3.74)$ & $10.31(3.06)$ & $87 \%$ & $14.55(6.23)$ & $11.50(5.64)$ & $79 \%$ \\
\hline August & $15.50(4.42)$ & $10.96(2.49)$ & $68 \%$ & $8.59(2.80)$ & $7.48(2.00)$ & $90 \%$ & $12.69(4.88)$ & $9.11(4.29)$ & $72 \%$ \\
\hline September & $11.77(4.68)$ & $7.96(1.56)$ & $66 \%$ & $8.84(2.95)$ & $6.86(2.79)$ & $82 \%$ & $12.13(4.52)$ & $8.78(4.59)$ & $72 \%$ \\
\hline October & $4.45(2.54)$ & $2.47(1.05)$ & $78 \%$ & $4.08(1.57)$ & $2.86(0.98)$ & $76 \%$ & $5.32(2.29)$ & $3.98(2.35)$ & $75 \%$ \\
\hline
\end{tabular}

Table V. Daily sap flux density $\left(\mathrm{kg} \mathrm{dm}^{-2} \mathrm{~d}^{-1}\right)$ at several depths in trunks of two beech trees (means over 4 intervals of 16 days during 2004 , standard deviation in brackets).

\begin{tabular}{|c|c|c|c|c|c|c|c|c|c|c|}
\hline Tree & & & ree 51 , diame & ter: $67.8 \mathrm{~cm}$ & & & & Tree 29, diame & ter: $43.9 \mathrm{~cm}$ & \\
\hline $\begin{array}{l}\text { Depth in the } \\
\text { trunk (mm) }\end{array}$ & $0-22$ & $22-44$ & $44-66$ & $66-88$ & $88-110$ & $110-132$ & $0-22$ & $22-44$ & $44-66$ & $66-88$ \\
\hline $05 / 20-06 / 04$ & 16.49 (3.59) & $20.02(4.60)$ & $5.24(1.38)$ & $5.81(1.53)$ & $3.38(1.19)$ & $4.911 .69)$ & $10.31(4.69)$ & $7.61(3.26)$ & $2.33(1.14)$ & $3.281 .44)$ \\
\hline 06/09-06/24 & $13.70(4.33)$ & $19.65(6.19)$ & $3.70(1.36)$ & $5.28(1.86)$ & $2.78(1.20)$ & $3.81(1.70)$ & $9.62(3.82)$ & $7.41(3.26)$ & $2.14(0.95)$ & $3.62(1.66)$ \\
\hline $06 / 25-07 / 10$ & 14.18 (3.78) & $20.49(5.41)$ & $3.59(1.20)$ & $5.23(1.54)$ & $2.60(0.99)$ & $3.56(1.45)$ & $11.41(4.60)$ & $7.52(2.59)$ & $2.40(1.34)$ & $3.42(1.81)$ \\
\hline $07 / 18-08 / 02$ & $16.30(2.79)$ & $23.78(4.55)$ & $4.09(0.97)$ & $6.32(1.29)$ & $3.39(0.97)$ & $4.81(1.41)$ & $16.42(4.75)$ & $12.56(3.85)$ & $3.13(1.26)$ & $4.03(1.56)$ \\
\hline
\end{tabular}

2003. Seasonally, the highest SFD values were observed during the summer in all cases.

Radial SFD gradients varied during the growing season (Tab. IV), with no consistent pattern among years. During the dry summer months of 2003, the gradient was less steep than during 2002 and 2004. The largest difference occurred during May 2004.

\subsection{Radial patterns}

Daily mean SFD at several depths in the trunks of trees 29 and 51 are presented in Table V. Weather and soil moisture conditions were balanced during measurement periods (see Tab. II). Regardless of changing potential evapotranspiration (PET) the fraction of cumulated SFD at different depths was almost constant (Fig. 2). The diurnal courses of SFD at four depths in tree 29 (Fig. 3) display a small time lag in the deeper sapwood compared to the outer rings.

The function presented in Figure 4 was based on Equation (4) with $n=80$ and $R^{2}=0.802$, and following parameters: $\alpha=10.457 ; \beta=0.15 ; \gamma=0.25 ; \delta=2.1 ; \varepsilon=0.021$.

The integration over intervals $(0,100 \%)$ and $(0,40 \%)$, respectively,

$$
\int_{0}^{r=100 \%} \mathrm{SFD}_{\text {rel }}=2027.5 \quad \int_{0}^{r=40 \%} \mathrm{SFD}_{\text {rel }}=1631.5
$$

showed that $80.5 \%$ of the total SFD is predicted to occur between cambium and a radial depth of $40 \%$. This was calculated assuming a decline of SFD to zero in the central trunk.

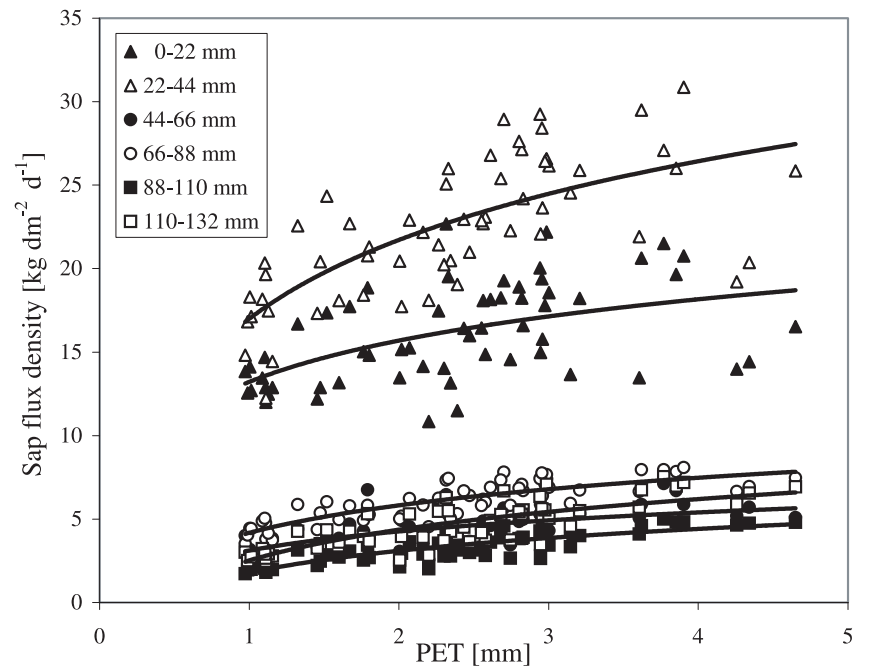

Figure 2. Relationship between potential evapotranspiration (PET) and daily sap flux density at six different depths in the trunk of tree 51, from May 20 to August 022004.

As our model is valid up to $r=40 \%$ only, we computed for the interior trunk besides the versions with (i) an instant SFD decline to zero at the radial depth of $40 \%$ as minimal and (ii) a steady SFD at the level of radial depth $40 \%$ as maximal possibilities (dashed lines in Fig. 4). At radial depth $40 \%$ a SFD rel was $13.3 \%$. 


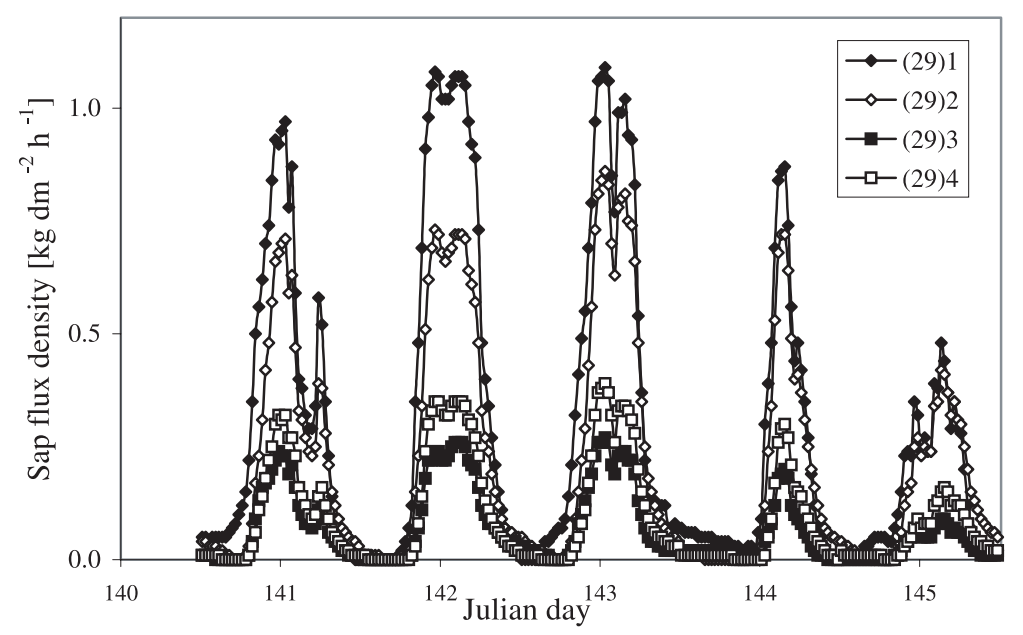

Figure 3. Daily curves of sap flux density at depths 0-22 mm (1), 22-44 mm (2), 44-66 mm (3) and 66-88 mm (4) of tree 29, from May 20 to May 242004.

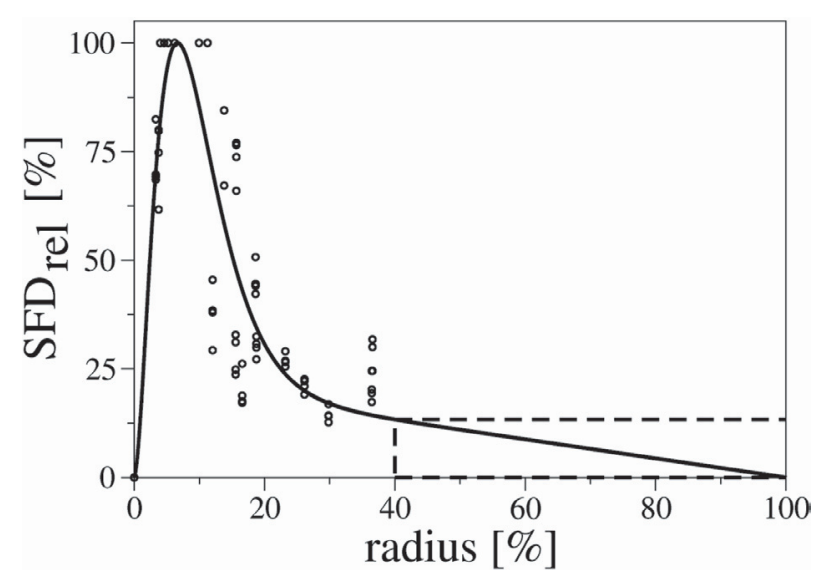

Figure 4. Radial profile of normalised sap flow density as a function of normalised radius: $\left(R^{2}=0.802, n=80\right)$. Model equation: $\mathrm{SFD}_{\mathrm{rel}}=$ $10.457\left(1-\mathrm{e}^{-0.15 r}\right)\left(10.457 \mathrm{e}^{-0.25 r} r+(2.1-0.021 r)\right)$. The model is valid up to $r=40 \%$. The dashed lines define the limits for a possible profile course beyond the validity range.

\subsection{Whole tree sap flux}

As an example, daily whole tree sap flux was calculated for two beech trees and a period of 16 days using the radial distribution model (Fig. 5). The crown of the dominant beech tree 51 transpired nearly $300 \mathrm{~kg}$ water during bright summer days with PET $>4 \mathrm{~mm}$ (see days 149-151). Whole tree transpiration was only 20 to $30 \%$ in tree 29 compared to the dominant tree 51. The results of minimal and maximal versions of the radial profile are given as error bars in Figure 5.

\section{DISCUSSION}

For computing stand transpiration from xylem sap flux density (SFD) measurements it is appropriate to group all trees of

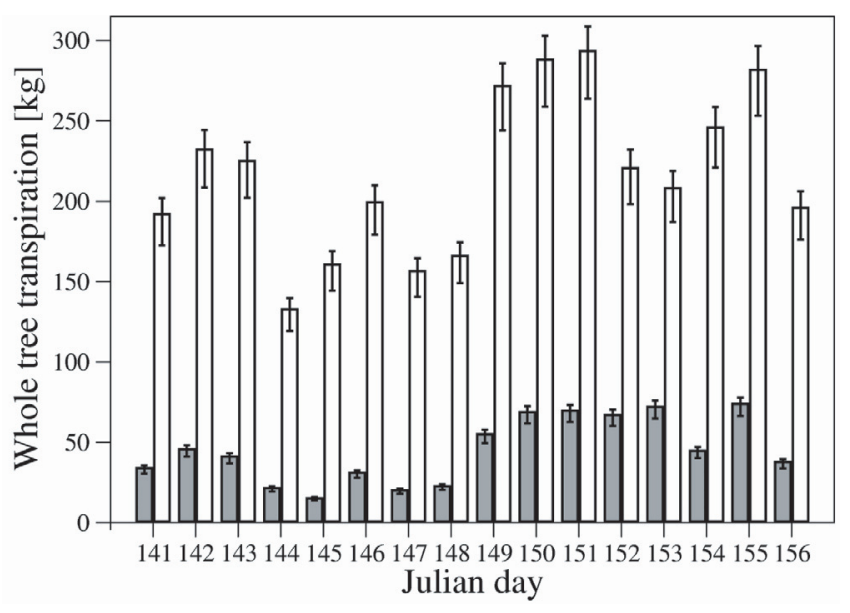

Figure 5. Whole tree transpiration of tree $51\left(d_{1.3}=67.8 \mathrm{~cm}\right.$, bright bars) and tree $29\left(\mathrm{~d}_{1.3}=43.9 \mathrm{~cm}\right.$, dark bars $)$ for the period May 20 to June 04 in 2004. Minimal and maximal version of radial profile course are given as error bars.

the stand according to diameter- or area classes [1,2,4,17]. Diurnal values of transpiration of individual trees are then a stratified random sample, the transpiration in $\mathrm{mm}$ being calculated from them via the basal area of the stand [5]. This procedure, however, may involve errors if (i) the measurements are only taken in the pericambial xylem and sap flux occurs in deeper xylem and (ii) the radial distribution of SFD varies substantially among trees with different trunk diameter [9]. For example, Granier et al. [14] found larger SFD in the xylem of dominant beech trees as compared to smaller trees. In general, we also found this to be the case in the ten representatives of our basal area classes. Relatively high SFD on smaller and thinner trees could be explained by the heterogeneity of the canopy structure. Due to residual gaps after pine tree felling, these trees were probably intercepting enough light or had an aboveaverage leaf area/basal area ratio. Vincke et al. [27] found that 
SFD variability was larger in a thinned than in an un-thinned oak stand.

The recorded SFD values were found to correlate positively with global radiation on all trees and at all depths. A trend towards saturation was found under high radiation at different thresholds for individual trees. This trend was also found by Kubota et al. [19]. They explain the responses to radiation partly as result of irradiance on stomatal opening, and the correlated change in vapour pressure deficit that occurs with changes in radiation. Tree structure and properties of the conducting system regulate transpiration at the whole plant level [11].

The beech trees revealed a decreased SFD in the inner trunk. This confirms earlier findings [14,17-19,21]. However, in very large trees we observed an increase of SFD in the depth sector of 22-44 mm with respect to the outer sector. Such an effect was also reported earlier for Fagus crenata [18].

Several normalisation procedure have been used to take into account radial profiles of SFD, like a 3-parameter Gaussian function with peak SFD occurring at $0-20 \mathrm{~mm}$ depth to data from Pinus spp. [9]. No SFD decrease was recorded by several authors in the outer $30-40 \mathrm{~mm}$ in diffuse-porous trees [8, 24, 25]. Radial measurements by Gessler et al. [10] on 95-year old beech trees revealed a constancy up to $60 \mathrm{~mm}$ depth. Wullschleger and King [28] found for individual trees a large heterogeneity with regard to radial distribution of sap flow velocity in yellow-poplar trees. Therefore, they consider that a sampling strategies taking into account radial variation in sap flow velocity is a prerequisite to compute stand transpiration. It cannot be excluded that the increase in outer sapwood, occurred similarly on thinner trees as well, but remained undetectable with the $22 \mathrm{~mm}$ long sensors. In large diameter trunks, the number of annual rings crossed by the xylem sap sensor is smaller, i.e. the resolution is larger than in slender trunks. To clarify this aspect, shorter sensors are required for future studies.

The most important question was that of the decrease of xylem sap flux density with depth in the trunk. Our measurements were performed to radial depths of $40 \%$. Using the function for radial SFD profile parameterised here, SFD at this depth was estimated at $13.3 \%$ of the maximum value. The SFD deeper in the trunk was not recorded and our model in this region remains. Our assumption was that SFD decreases gradually to zero in the middle of the trunk. An instant decline of SFD to zero is less likely. In this case our model would overestimate whole tree transpiration by $10.1 \%$. A constant SFD to the centre of the trunk seems unlikely. This case would mean an underestimation of whole tree sap flux by $5.2 \%$.

For whole tree transpiration, large differences were found between the dominant tree 51 and the middle class tree 29 . The transpiration of tree 29 was only about $20-30 \%$ of tree 51 , while, the cross sectional area ratio was 2 to 5 .

Our model of radial xylem sap flux density profiles was devised on the basis of data from representative trees of all basal area classes. Even if it is only reliable a depth of $40 \%$ of the total radius, it can be used with adequate accuracy for assessing whole tree transpiration. Measuring SFD in the outer trunk sector is then sufficient, as $90 \%$ of the total water flow occurs in the outer two fifths of the trunk.

Acknowledgements: We thank Bodo Grossmann for construction and servicing the sap flow measuring systems and Erwin Dreyer for thorough linguistical revision of the text. The investigations were funded by the monitoring program of the Leibniz-Center of Agricultural Landscape Research (ZALF).

\section{REFERENCES}

[1] Alsheimer M., Charakterisierung räumlicher und zeitlicher Heterogenität der Transpiration unterschiedlicher montaner Fichtenbestände (Picea abies (L.) KARST.) durch Xylemflußmessungen, Dissertation, Bayreuther Forum Ökologie 49/19, Selbstverlag BITÖK, Bayreuth, 1997, 140 p.

[2] Breda N., Cochard H., Dreyer E., Granier A., Water transfer in a mature oak stand (Quercus petraea): seasonal evolution and effects of severe drought, Can. J. For. Res. 23 (1993) 1136-1143.

[3] Čermák J., Nadezhdina N., Sapwood as the scaling parameter defining according to xylem water content or radial pattern of sap flow? Ann. Sci. For. 55 (1998) 509-521.

[4] Čermák J., Kučera J., Nadezhdina N., Sap flow measurements with some thermodynamic methods, flow integration with trees and scaling up from sample trees to entire forest stands, Trees 18 (2004) $529-546$

[5] Cienciala E., Lindroth A., Čermák J., Hällgren J.-E., Kučera J., Assessment of transpiration estimates for Picea abies trees during a growing season, Trees (1992) 121-127.

[6] Cohen Y., Kelliher F.M., Black T.A., Determination of sap flow in Douglas-fir trees using the heat pulse technique, Can. J. For. Res. 15 (1985) 422-428.

[7] Dietrichs H.H., Chemische-physiologische Untersuchungen über die Splint-Kern-Umwandlung der Rotbuche (Fagus sylvatica L.) - Ein Beitrag zur Frage der Holzverkernung, Mitteilungen der Bundesforschungsanstalt für Forst- und Holzwirtschaft 58, Hamburg, Germany, BFH/Wiedebusch, 1964, 141 p.

[8] Edwards W.R.N., Brooker R.E., Radial variation in the axial conductivity of Populus and its significance in heat pulse velocity measurement, J. Exp. Bot. 35 (1984) 551-561.

[9] Ford C.R., McGuire M.A., Mitchell R.J., Teskey R.O., Assessing variation in the radial profile of sap flux density in Pinus species and its effect on daily water use, Tree Physiol. 24 (2004) 241-249.

[10] Gessler A., Rienks M., Dopatka T., Rennenberg H., Radial variation of sap flow densities in the sap-wood of beech trees (Fagus sylvatica L.), Phyton 45 (2005) 257-266.

[11] Grace J., Consequences of xylem cavitation for plant water deficits. In: Water deficits, plants responses from cell to community, Smith J.A.C., Griffiths H. (Eds.), Bio Oxford, 1993, pp. 109-128.

[12] Granier A., Une novelle méthode pour la mesure du flux de sève brute dans le tronc des arbres, Ann. Sci. For. 42 (1985) 193-200.

[13] Granier A., Anfodillo T., Sabatti M., Cochard H., Dreyer E., Tomasi M., Valentini R., Breda N., Axial and radial water flow in the trunks of oak trees: a quantitative and qualitative analysis, Tree Physiol. 14 (1994) 1383-1396.

[14] Granier A., Biron P., Lemoine D., Water balance, transpiration and canopy conductance in two beech stands, Agric. For. Meteorol. 100 (2000) 291-308. 
[15] Hinckley T.M., Lassoie J.P., Running S.W., Temporal and spatial variations in the water status of forest trees, For. Sci. Monogr. 20, $1978,72 \mathrm{p}$

[16] Kaufmann M.R., Kelliher F.M., Measuring transpiration rates, in: Lassoie J.P., Hinckley T.M. (Eds.), Techniques and approaches in forest tree ecophysiology, CRC Press, Boca Raton (1991) 117-140.

[17] Köstner B., Granier A., Čermák J., Sapflow measurements in forest stands: methods and uncertainties, Ann. Sci. For. 55 (1998) 13-27.

[18] Kubota M., Tenhunen J., Zimmermann R., Schmidt M., Kakubari Y., Influence of environmental conditions on radial patterns of sap flux density of a 70-year Fagus crenata trees in the Naeba Mountains, Japan, Ann. For. Sci. 62 (2005) 289-296.

[19] Kubota M., Tenhunen J., Zimmermann R., Schmidt M., Adiku S., Kakubari Y., Influences of environmental factors on the radial profile of sap flux density in Fagus crenata growing at different elevations in the Naeba Mountains, Japan, Tree Physiol. 25 (2005) $545-556$.

[20] Kvålseth T.O., Cautionary note about $R^{2}$, Am. Stat. 39 (1985) 279-285.

[21] Lang S., Ökophysiologische und anatomische Untersuchungen zum Saftfluß in verschiedenen Splintholzbereichen von Fagus sylvatia L., Diss., Karlsruher Beitr. Pflanzenphysiol. 35, 1999, 184 p.
[22] Lüttschwager D., Rust S., Wulf M., Forkert J., Hüttl R.F., Transpiration and water relations in Scots pine (Pinus sylvestris L.) stands with different structures in the herb layer, Ann. For. Sci. 56 (1999) 265-274.

[23] Monteith J.L., Evaporation and environment, Soc. Exp. Biol. Symp. 29 (1965) 205-235.

[24] Pausch R.C., Grote E.E., Dawson T.E., Estimating water use by sugar maple trees: Considerations when using heat-pulse methods with deep functional sapwood, Tree Physiol. 20 (2000) 217-227.

[25] Phillips N., Oren R., Zimmermann R., Radial patterns of xylem sap flow in non-, diffuse- and ring-porous tree species, Plant Cell Environ. 19 (1996) 983-990.

[26] Tenhunen J., Landschaftsbezogene Erfassung des Wasserverbrauches bewirtschafteter Waldbestände, in: Matzner E. (Ed.) Grundlagen zur nachhaltigen Entwicklung von Ökosystemen bei veränderter Umwelt, BITÖK Forschungsbericht, Bayreuther Forum Ökologie 84, Bayreuth, 2001, pp. 305-315.

[27] Vincke C., Breda N., Granier A., Devillez F., Evapotranspiration of a declining Quercus robur (L.) stand from 1999 to 2001. I. Tree and forest floor daily transpiration, Ann. For. Sci. 62 (2005) 503-512.

[28] Wullschleger S.D., King A.W., Radial variation in sap velocity as a function of stem diameter and sapwood thickness in yellow-poplar trees, Tree Physiol. 20 (2000) 511-518. 